\title{
Monitoring riparian restoration to ensure recruitment of large woody debris in Haida Gwaii, British Columbia
}

\author{
by Alexandra L. Ryland ${ }^{1}$ and Sean C. Thomas ${ }^{2}$
}

\begin{abstract}
Monitoring is a fundamental aspect of restoration, as it determines when the restoration objectives have been met. As restoration objectives are not universal, monitoring needs to be included in the development and design of each restoration project. We assessed the effectiveness and efficiency of a forest stand dynamic monitoring plan, developed for use with riparian restoration occurring on Lyell Island, Haida Gwaii, British Columbia. The restoration objective is to accelerate the development of late-successional forests for the benefit of riparian wildlife species and recruitment of in-stream large woody debris, which specifically provides essential habitat for a variety of fish species. In this study large woody debris (LWD) is referred to as downed wood greater than $7.5 \mathrm{~cm}$ in diameter. Prior to the start of riparian restoration, two watersheds were quantified for their stand structure and composition using the forest stand dynamic monitoring plan. An error analysis of these data was used to assess the sampling efficiency of the monitoring plan. The design of the monitoring plan was found to be efficient at monitoring the riparian forest stand dynamics (with seven or eight plots per site sufficient to evaluate stand basal area and stem density to within 10\%), but not woody debris volumes (for which deviations $>10 \%$ were found even with 14 plots per site). Incorporation of additional line transects or adoption of more efficient sampling methods for woody debris (such as diameter or length relascope methods) is suggested as a means of enhancing large woody debris sampling efficiency.
\end{abstract}

Key words: large woody debris, ecological monitoring, error analysis, riparian zone restoration

\section{RÉSUMÉ}

Le suivi constitue un aspect fondamental de la restauration puisqu'il permet de déterminer si les objectifs de restauration ont été atteints. Compte tenu que les objectifs de restauration ne sont pas universels, le suivi doit être envisagé lors de lélaboration et de la conception de chaque projet de restauration. Nous avons évalué l'efficacité et lefficience d'un plan de la dynamique des peuplements forestiers, élaboré pour être utilisé dans la restauration des rives effectuée sur l’île Lyell, Haida Gwaii, en Colombie-Britannique. L'objectif de la restauration est d'accélérer le développement des forêts de fin de la série évolutive pour le bénéfice des espèces fauniques retrouvées sur les rives et la génération de gros débris de bois dans les cours d'eau ce qui procure spécifiquement un habitat essentiel à de nombreuses espèces de poissons. Au cours de cette étude, les gros débris de bois (GDB) font référence à des morceaux de bois tombé au sol de plus de $7,5 \mathrm{~cm}$ de diamètre. Avant d’amorcer la restauration des rives, deux bassins hydrographiques ont été mesurés relativement à leur structure de peuplement et à leur composition au moyen d'un plan de suivi du comportement des peuplements. Une analyse numérique de ces données a été effectuée afin dévaluer l'efficience de léchantillonnage du plan de suivi. La conception du plan de suivi sest avérée être efficiente au niveau de l'évaluation du suivi de la dynamique des peuplements forestiers riverains (l'utilisation de sept ou huit parcelles par site étant suffisante pour évaluer la surface terrière du peuplement et la densité des tiges à près de $10 \%$ ), mais pas dans le cas du volume des débris ligneux (pour lequel des écarts $>10 \%$ ont été relevés même avec 14 parcelles par site). Laddition de lignes de transect supplémentaires ou l'utilisation de méthodes déchantillonnage plus efficientes des débris ligneux (comme les méthodes de mesurage du diamètre ou de la longueur au moyen du relascope) est suggérée en tant que mesure d'accroissement de l'efficience de léchantillonnage des gros débris ligneux.

Mots clés : gros débris ligneux, suivi environnemental, analyse numérique, restauration des zones riveraines

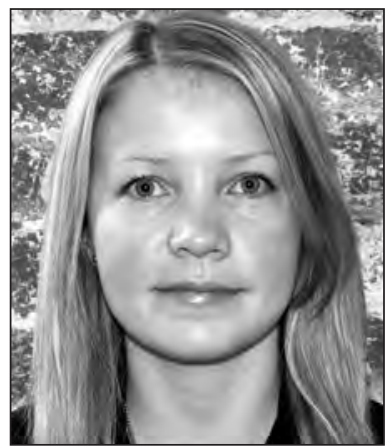

Alexandra L. Ryland

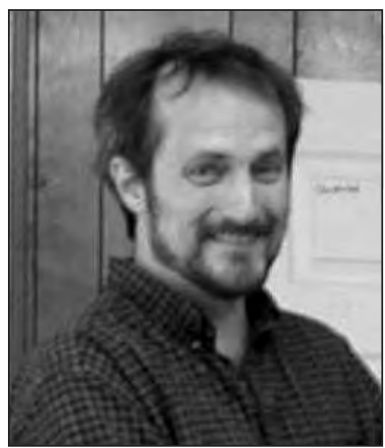

Sean C. Thomas

\footnotetext{
${ }^{1}$ Faculty of Forestry, University of Toronto, 33 Willcocks St., Toronto, Ontario M5S 3B3. E-mail: alex.ryland@utoronto.ca

${ }^{2}$ Professor, Faculty of Forestry, University of Toronto, 33 Willcocks St., Toronto, Ontario M5S 3B3. E-Mail: sc.thomas@utoronto.ca
} 


\section{Introduction}

Riparian forests are among the most biologically diverse ecosystems within the terrestrial landscape, providing habitat for many wildlife species (Pollock et al. 2005). These areas are also extremely productive within the aquatic landscape, influencing stream function by generating fine organic material, nutrients, and sediments, and by providing bank stability, shade and large woody debris (LWD), all essential components for fish habitat (Fetherston et al. 1995, Welty et al. 2002, Opperman and Merenlender 2004, Pollock et al. 2005). Modification of riparian ecosystems caused by forest harvesting practices has historically occurred in much of North America (Davis et al. 2004, Pollock et al. 2005). This modification can create dramatic shifts in riparian biological characteristics and stream productivity. In British Columbia specifically, salmon populations have been adversely affected as a direct result of streamside logging practices (Opperman and Merenlender 2004).

Restoration is the return of an ecosystem to its condition prior to disturbance, with the general objective of producing a self-sustaining ecosystem that is resilient to change (Kondolf and Micheli 1995, Wissmar and Beschta 1998, Ruiz-Jaen and Aide 2005). There are many different ways to restore an ecosystem, each using different approaches and techniques to help achieve restoration objectives. The literature suggests that when restoration is focused on restoring salmon habitat, techniques that restore natural habitat-forming processes, such as riparian vegetation, can be more advantageous than the placement of unnatural in-stream habitat structures (Opperman and Merenlender 2004). LWD is the primary determinant of stream channels forming pools, regulating the transport of organic matter, nutrients and sediments, and providing a multitude of habitats that support a variety of species of fish, macroinvertebrates and algae (Fetherston et al. 1995, Beechie et al. 2000, Welty et al. 2002, Johnston et al. 2007). The removal of riparian vegetation through forest harvesting can eliminate the recruitment of in-stream LWD for several decades, affecting fish habitat and consequently fish quantity (Beechie et al. 2000, Welty et al. 2002). The length of time between riparian vegetation removal and LWD recruitment depends in part on the species composition of the regenerating stand (Beechie et al. 2000). Conifer species are favoured for in-stream LWD habitat because their rates of decomposition are slow compared to hardwoods in the region. As some conifer species can take up to 75 years after logging to start recruitment of LWD (Beechie et al. 2000), silvicultural manipulation can be used as a restorative tool to assist riparian vegetation regrowth. Thinning can help reduce the recovery time for recruitment of LWD by increasing growth rates of selected conifer riparian trees (Beechie et al. 2000, Pollock et al. 2005).

Monitoring is an integral part in determining when restoration objectives have been met (Pollock et al. 2005, Herrick et al. 2006), and must be included in the development and design of each restoration project to ensure restoration success (Kondolf and Micheli 1995, Davis et al. 2004, Pollock et al. 2005). A suitable monitoring design, along with appropriate variables to be measured, needs to be identified to ensure monitoring effectiveness and efficiency (Kondolf and Micheli 1995). Criteria will depend on the objectives of the restoration. For example, Pollock et al. (2005) state that if the restoration objective is to increase LWD in a riparian forest, the appropriate variables to be measured over time are diameter, length, species, decay class, and location relative to stream. The intensity and length of sampling in the monitoring program will depend largely on the scale of the restoration (Pollock et al. 2005). If inappropriate variables are measured and inappropriate sampling designs implemented, monitoring programs can incorrectly predict failure of restoration that was successful, or the success of restoration that ultimately failed (Herrick et al. 2006). Monitoring appropriateness for restoration is a widely accepted concept; however, formal studies that assess monitoring sampling efficiency are lacking within the literature.

Haida Gwaii is an archipelago $80 \mathrm{~km}$ off the coast of the Province of British Columbia, and contains some of the richest ecological, cultural and political landscape in the world (Takeda and Røpke 2010). Referred to as the "Galápagos of the North", Haida Gwaii contains many endemic species and sub-species of plants and animals. Throughout the early $20^{\text {th }}$ Century, much of landscape of Haida Gwaii was subject to extensive clear-cut logging (Davis et al. 2004). This accelerated industrial forestry led to a public outcry and a series of protests against the forest industry on the islands. In 1987, the Canadian government responded by creating Gwaii Haanas National Park Reserve and Haida Heritage Site (herein Gwaii Haanas), which includes the southernmost 15\% of Haida Gwaii (Davis et al. 2004). Gwaii Haanas is focused on restoring the degraded landscape caused by the improper forestry operations. Logging can negatively impact streams by increasing fine and coarse sediment, shifting hydrological processes, and altering the delivery of LWD and organic matter to streams (Roni 2005). Currently, the focus within Gwaii Haanas is to restore damaged streams that once provided salmon spawning and rearing habitat through in-stream and riparian forest restoration. This restoration program is called Yahgudang dlljuu: A Respectful Act, and is coordinated and funded by Parks Canada, as part of its Action-on-the-Ground funding that was announced in 2008 (Parks Canada 2011). Gwaii Haanas has partnered with the Haida Fisheries Program (HFP), the Hecate Straight Streamkeepers (HSS), and the Ministry of Forests, Lands and Natural Resource Operations (FLNRO), to ensure the completion of the Yahgudang dlljuu: A Respectful Act program.

Riparian restoration can be achieved in two ways: the placement of in-stream habitat structure or the physical manipulation of the riparian forest vegetation. The placement of in-stream habitat structure is an active restoration tool, whereas the manipulation of the riparian forest is a passive restoration tool (Opperman and Merenlender 2004). Both restoration tools are being employed in Gwaii Haanas. The HFP and the HSS are working together for the in-stream restoration and the FLNRO is facilitating the riparian forest restoration. A silvicultural prescription focused on thinning was developed for the riparian forests within the Sandy Creek and Powrivco Creek watersheds, located on Lyell Island, Gwaii Haanas (Fig. 1). The thinning prescription focused on improving the growth in diameter of conifer trees within the riparian forests for securing a long-term supply of LWD. A forest stand-dynamics monitoring plan was developed to assess the success of this riparian forest restoration.

The present research investigates the effectiveness of the forest stand-dynamics monitoring plan and the effectiveness of the riparian forest restoration at securing the recruitment 


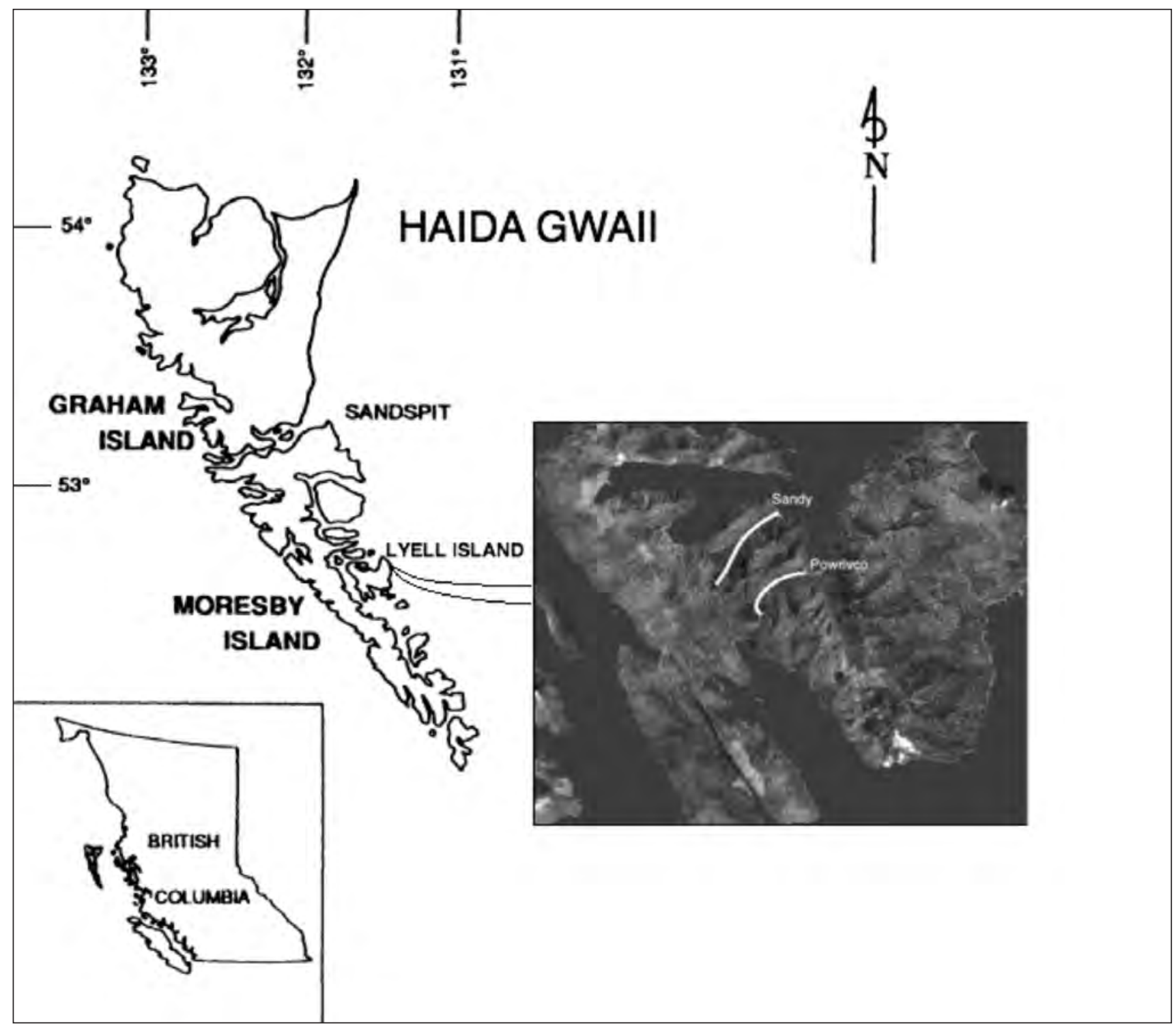

Fig. 1. The restoration sites are on Lyell Island surrounding Sandy Creek and Powrivco Creek.

of LWD within Gwaii Haanas, Haida Gwaii, British Columbia. The research objectives are (1) to quantify current stand characteristics of the riparian forests on Lyell Island, and (2) to assess the sampling efficiency of the forest stand dynamics monitoring plan in relation to projected changes in forest structure and composition in treated stands.

\section{Methods}

\section{Site description}

Research was conducted on Lyell Island, $65 \mathrm{~km}$ south of the village of Queen Charlotte, Haida Gwaii. Lyell Island is the largest island within Gwaii Haanas, approximately 17500 ha, and part of the Skidegate Plateau ecosection on Haida Gwaii. The forest falls within the Costal Western Hemlock Submontane Wet Hypermaritime Biogeoclimatic Zone (CWHwh1) (Banner et al. 2005). Annual precipitation ranges from 5000 $\mathrm{mm}$ in the west to $1400 \mathrm{~mm}$ in the east (Allombert et al. 2005). The dominant tree species found within the riparian areas on Lyell Island are western hemlock (Tsuga heterophylla
[Raf.] Sarg.), Sitka spruce (Picea sitchensis [Bong.] Carrière), and red alder (Alnus rubra Bong.). The study sites were within the Sandy Creek and Powrivco Creek watersheds, measuring $\sim 581$ ha and $\sim 412$ ha, respectively. Restoration sites are located within the riparian forest surrounding Sandy and Powrivco Creeks measured 11.2 ha and 7.2 ha, respectively, and represent regenerating forest logged 65 years prior to sampling.

\section{Forest stand dynamics monitoring plan}

The Forest and Range Evaluation Program (FREP) was suggested as a potential monitoring framework that could be adapted for use within Gwaii Haanas to monitor riparian forest restoration. FREP is a legislated program governed by the provincial government of British Columbia, which is used to assess whether the government-stated objectives for the Forest and Range Practices Act (FRPA) resource values are being achieved. There are eleven resource values included in FRPA that FREP looks to assess: biodiversity, cultural heritage, 
fish/riparian, forage and associated plant communities, recreation, resource features, soils, timber, visual quality, water, and wildlife. As FREP monitoring is in broad use on Crown land throughout British Columbia, its usefulness within Gwaii Haanas is of particular interest to the FLNRO.

Riparian forest restoration for both Sandy Creek and Powrivco Creek watersheds commenced in September 2011. The forest stand dynamic monitoring plan was implemented over a three-day period at the end of August 2011 to collect pre-restoration stand characteristics for both Sandy Creek and Powrivco Creek riparian forests. The monitoring plan focuses on the FRPA resource value biodiversity, utilizing the FREP stand-level biodiversity protocol (Densmore et al. 2009). The stand-level biodiversity protocol collects forest stand dynamics data through permanent sample plots. A nested fixed area plot design was selected for monitoring forest stand dynamics. An overstory vegetation plot $\left(500 \mathrm{~m}^{2}\right)$ was used for inventorying all standing trees with a diameter at breast height $(\mathrm{DBH}) \geq 12.5 \mathrm{~cm}$. For each tree, $\mathrm{DBH}$, species, wildlife tree class and height were recorded. An understory vegetation plot $\left(50 \mathrm{~m}^{2}\right)$ was used for inventorying all standing trees with a $\mathrm{DBH}<12.5 \mathrm{~cm}$. For understory vegetation, counts of trees and species were recorded, based on size classification of pole (DBH 7.5-12.4 cm), sapling (DBH $<7.5 \mathrm{~cm}$ ), and seedling (regeneration $<50 \mathrm{~cm}$ in height). LWD greater than $7.5 \mathrm{~cm}$ in diameter was measured along a 30 - $\mathrm{m}$ transect starting at plot centre within the permanent sample plot, recording the diameter, species, decay class, and length of each piece that came into contact with the transect. The common fiveclass system was used for determining LWD decay class; however, the fifth class was omitted from data collection (Densmore et al. 2009). If a piece of LWD crossed the transect more than once, it was counted and recorded each time as a separate piece. The following equation was used to convert this line transect data into LWD volume estimates per unit area (Van Wagner 1968):

$$
\text { [1] } v=\frac{\pi^{2} \sum d^{2}}{8 L}
$$

where $v$ equals LWD volume in cubic meters per hectare, $L$ equals the transect length $(30 \mathrm{~m})$, and $d$ equals the diameter of LWD in metres.

In total, 14 permanent sample plots were established within the riparian forests surrounding Sandy Creek, while nine permanent sample plots were established surrounding Powrivco Creek. Sandy Creek has more monitoring plots as the treatment area for restoration is larger than Powrivco Creek.

\section{FVS model description}

Forest Vegetation Simulator (FVS, U.S. Forest Service 1996) is a distance-independent, individual-tree forest growth model used to help support management decisions (Crookston and Dixon 2005). There are 20 different versions (variants) of the software available from the U.S. Forest Service, depending on the location one is trying to represent in one's simulation. The Southeast Alaska and Coastal British Columbia variant of FVS was selected for this research as it was fit to data representing a hemlock-Sitka spruce forest type, and data from Haida Gwaii were used in initial model development (Keyser
2011). This variant simulates forest stand growth for a wide variety of management prescriptions and species, and produces outputs including change in diameter, height, and trees per hectare of each species at 10-year intervals (Beechie et al. 2000). The model was used to describe changes in riparian stand structure and composition through time and to estimate the number and size of trees that die and can provide LWD to the adjacent streams. The pre-restoration stand characteristics data collected from the monitoring permanent sample plots were used as the input data for the model simulation. To represent the riparian restoration, a thinning management option was selected from the program, and a residual density of trees per hectare was specified. Western hemlock was selected for preferential cutting in simulation scenarios using FVS.

\section{Simulation of accuracy}

A simulation of accuracy as a function of sampling effort was completed to assess sampling efficiency of variables within the monitoring plan. This analysis quantifies the number of permanent sample plots that are needed to adequately represent the average riparian forest conditions. We used a bootstrapping approach to estimate accuracy as a function of sample size based on observed data (Manly 2007). The estimation of error for tree density and LWD volume was calculated as the relative difference between the variable measurement and the true mean value of that variable:

$$
\text { [2] } R D=\frac{a b s\left(x_{i}-\mu\right)}{\mu}
$$

where $R D$ is equal to the relative difference, $x_{\mathrm{i}}$ is the bootstrapped estimate of the mean of a stand structure variable (e.g., tree density) at a given sample size, and $\mu$ is equal to the true mean value of that variable (estimated as the observed mean including all replicates at a given site). Five thousand boot samples were at each sample size were utilized in simulations. Analyses utilized the statistical programming language R (R Development Core Team 2011).

\section{Measurement error assessment}

An assessment of measurement error was completed within the riparian forest of Powrivco Creek. The forest stand dynamic sampling procedure was repeated to gain a second pre-restoration dataset. This second dataset (collected on August 28th) was then compared to the original dataset (collected on August 27th) from the Powrivco Creek riparian forest to assess the measurement error associated with the monitoring plan. Root-mean square error is often used to assess the difference between two values that are predicting the same thing (Gertner 1990, Phillips et al. 2000), and was used to assess measurement error of the forest stand dynamic monitoring plan. Root-mean square error (RMSE) is calculated using the following equation:

$$
\text { [3] } R M S E=\sqrt{\frac{\sum_{i=1}^{n}\left(x_{1, i}-x_{2, i}\right)^{2}}{n}}
$$

where $x_{1, i}$ is the $i^{\text {th }}$ measurement in the original dataset, $x_{2, i}$ is the $i^{\text {th }}$ measurement of same re-sampled variable, and $n$ is equal to the number of measurements for that given variable. 
Root-mean square error estimates were calculated for different variables within the monitoring plan: $\mathrm{DBH}$, height, wildlife tree class, and LWD volume.

\section{Results}

Both sampled sites had structural characteristics indicative of regenerating forest that deviates strongly from old-growth forest conditions in the region. The Sandy Creek site had an average stand basal area of $83.4 \mathrm{~m}^{2} \mathrm{ha}^{-1}$, with 737 trees per ha, with $83 \%$ Sitka spruce and $17 \%$ western hemlock (Fig. 2a). There was a missing component of large western hemlock ( $>60 \mathrm{~cm} \mathrm{DBH})$ and a lack of large snags. Small diameter snags dominate this riparian forest, which is not conducive to LWD supply or wildlife habitat. Powrivco Creek had a stand basal area of $76.6 \mathrm{~m}^{2} \mathrm{ha}^{-1}$, with 700 trees per hectare. The forest composition was 34\% Sitka spruce, $27 \%$ western hemlock, and 39\% red alder (Fig. 2b). This site likewise shows few large trees or large snags, but many small-diameter snags. The sapling component $(\mathrm{DBH}<7.5 \mathrm{~cm})$ was 18 trees per ha at
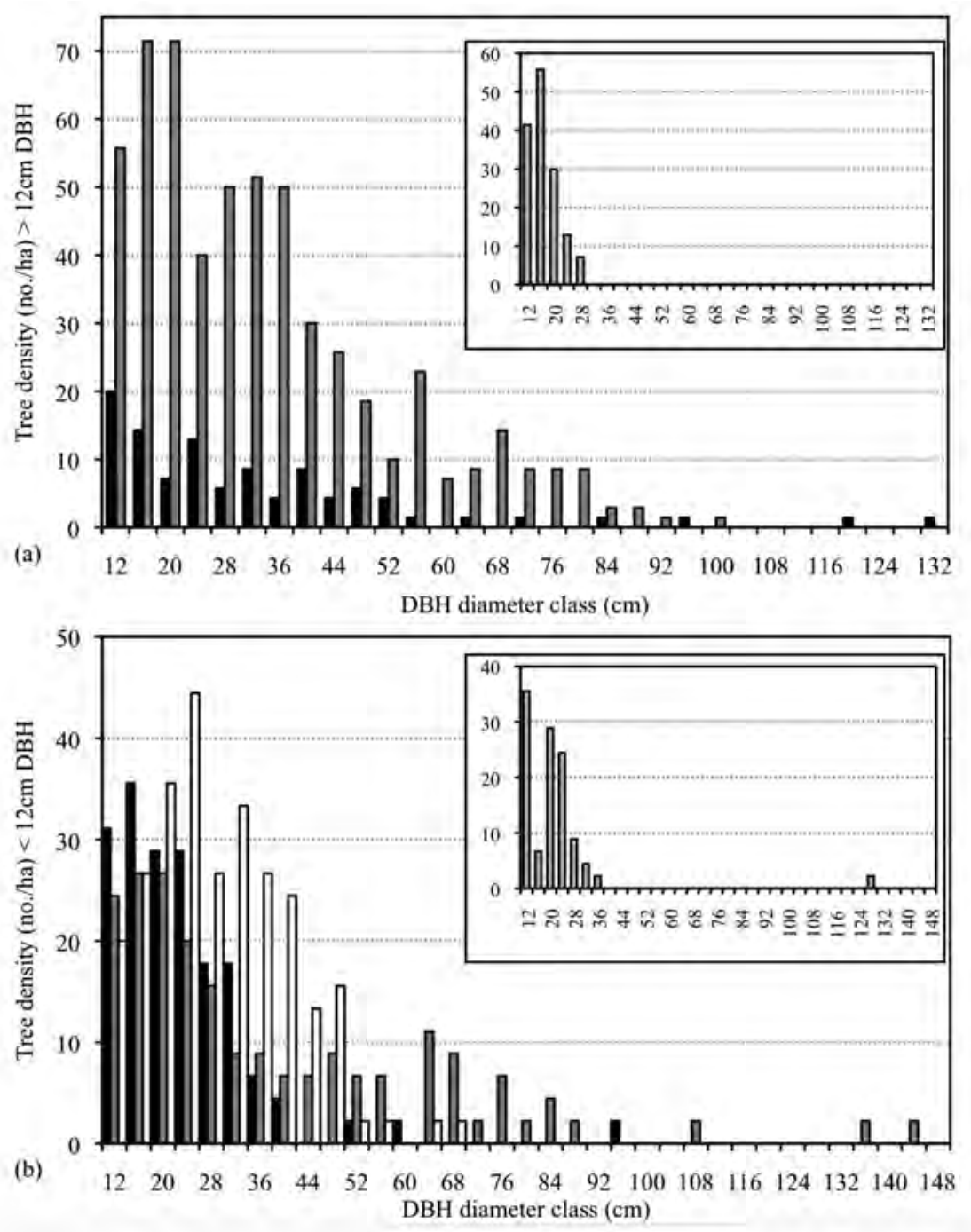

Fig. 2. Diameter frequency distribution of western hemlock (black bars), Sitka spruce (grey bars), and red alder (white bars) in the Sandy Creek watershed (a) and Powrivco Creek watershed (b). Insets show the amount of snag trees. Data is represented in trees per hectare.
Sandy Creek and 157 trees per ha at Powrivco Creek; both sites are largely missing the pole component $(\mathrm{DBH} 7.5 \mathrm{~cm}$ to $12.4 \mathrm{~cm}$ ) and have negligible shrub, herb, and regeneration layers. The riparian forests of Sandy Creek and Powrivco Creek are structurally simple, having a single canopy layer, a limited number of species, relatively little understory and few standing or fallen dead trees.

Coarse woody debris volumes for both Sandy Creek and Powrivco Creek riparian forests are missing the component of recently downed wood (decay class 1 ; Fig. 3). The volume of decay class 4 was high for both forests, likely representing woody debris generated during harvests; however, this decay class has extensive decay, is fully settled on the ground, and lacks structure for wildlife habitat, specifically small mammals (Hayes et al. 1997).

\section{FVS model predictions}

The pre-restoration stand data from the Sandy Creek and Powrivco Creek riparian forests were used to project the future riparian stand characteristics. The post-restoration projection shows an immediate increase in downed wood as a result of thinning. The 100 -year projection demonstrates an increased growth in tree diameter and height, predicting conifer release (Table 1). The average projected DBH of the Sandy Creek stand increases from 35.8 $\mathrm{cm}$ (at the start of the simulation, in 2011) to $51.9 \mathrm{~cm}$ in year 2111; the average height of the stand increases from $28.2 \mathrm{~m}$ to $48.5 \mathrm{~m}$ in year 2111. The projected average $\mathrm{DBH}$ of at Powrivco Creek increases from $34.1 \mathrm{~cm}$ to 52.3 $\mathrm{cm}$ in 2111; the average height of the stand increases from $24.1 \mathrm{~m}$ to $48.2 \mathrm{~m}$ in 2111 . The 100 -year projection also shows a decrease in tree density; however, this is still above estimated tree densities in old-growth stands in the region (Table 1 ).

\section{Simulation of sampling accuracy}

The simulation of accuracy depicts the relative mean difference between the measured variable and the true mean value of that variable. As the Stand-Level Biodiversity protocol requires an accuracy of within $10 \%$ of the true mean for all measurements (Densmore et al. 2009), 10\% was selected as the desired threshold accuracy. For the nine sample plots at Sandy Creek, tree density measurements are found within $8 \%$, and basal area within $6 \%$, of the estimated true means; for the 


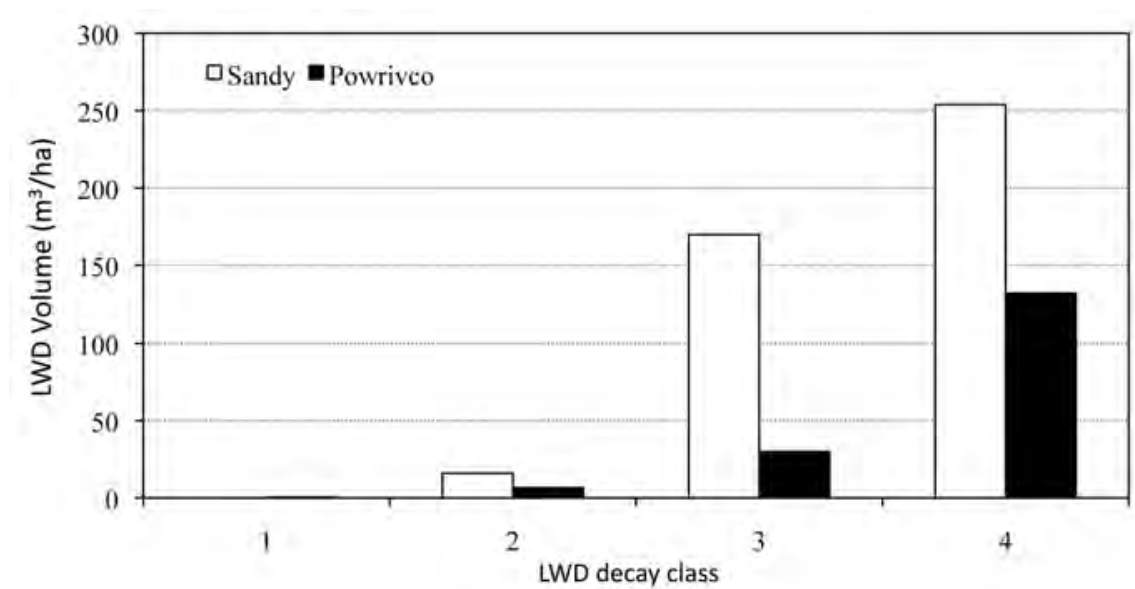

Fig. 3. Estimated LWD volume in both the Sandy Creek and Powrivco Creek watersheds. Data are shown in volume per hectare.

Table 1. Old-growth forest stand characteristics representative of the CWHwh1 Biogeoclimatic Zone (Banner et al. 2005), compared to the current stand characteristics on Lyell Island and 100-year FVS projections.

\begin{tabular}{lccccc}
\hline Forest type & $\begin{array}{c}\text { Average } \\
\text { DBH } \mathbf{( c m})\end{array}$ & $\begin{array}{c}\text { Density } \\
(\mathbf{s t e m s} / \mathbf{h a})\end{array}$ & $\begin{array}{c}\text { Basal area } \\
\left(\mathbf{m}^{\mathbf{2}} \mathbf{h a}^{\mathbf{- 1}}\right)\end{array}$ & $\begin{array}{c}\text { Dead wood } \\
\left(\mathbf{m}^{\mathbf{3}} \mathbf{h \mathbf { h } ^ { - 1 }}\right)\end{array}$ & $\begin{array}{c}\text { Average } \\
\text { height }(\mathbf{m})\end{array}$ \\
\hline Sandy Creek (2011 measured) & 35.8 & 737 & 83.4 & 439.7 & 28.2 \\
Sandy Creek (2111 projection) & 51.9 & 310 & 70.9 & 754.8 & 48.5 \\
Powrivco Creek (2011 measured) & 34.1 & 700 & 76.6 & 169.2 & 24.1 \\
Powrivco Creek (2111 projection) & 52.3 & 350 & 66.3 & 290.5 & 48.2 \\
Old-growth & 63.3 & 189 & 55.1 & $\mathbf{-}^{\mathrm{a}}$ & - \\
\hline
\end{tabular}

aUnavailable

14 sample plots at Powrivco Creek, tree density measurements are found within $9 \%$, and basal area within $7 \%$, of the estimated true mean. Sampling of LWD volume was found to be much less efficient at both sites. For the nine sample plots at Sandy Creek, LWD volume measurements are within $17 \%$ of the estimated true mean, and for the 14 sample plots at Powrivco Creek, LWD volume measurements are within 15\% of the estimated true mean (Fig. 4). The forest stand dynamic monitoring plan is thus under-sampling LWD volume in the riparian forests on Lyell Island.

\section{Measurement Error Assessment}

The riparian forest of Powrivco Creek was re-sampled on August $28^{\text {th }}$ using the forest stand dynamics monitoring plan to obtain a second pre-restoration dataset. This dataset was compared to the original dataset collected on August $27^{\text {th }}$ to analyze the amount of measurement error associated with the forest stand dynamic monitoring plan (Fig. 5). Measurement error for $\mathrm{DBH}$ values was low $(\mathrm{RMSE}=1.76 \mathrm{~cm})$, even though differences were observed between the $\mathrm{DBH}$ datasets. The associated measurement error for height values (RMSE = $3.16 \mathrm{~m}$ ) was higher than the measurement error for $\mathrm{DBH}$ values. The measurement error calculated for wildlife tree class observations was roughly one class unit $(\mathrm{RMSE}=1.11)$. Con- siderably higher measurement error was calculated for the LWD volume estimates. Collection of LWD datasets had relatively low repeatability, with a rootsquared mean error value of $10.94 \mathrm{~m}^{3} \mathrm{ha}^{-1}$ (Fig. 5).

\section{Discussion}

The current stand structure and composition of the riparian forests on Lyell Island indicate the need for restorative action, with stands not approaching structural characteristics representative of old-growth riparian forests in the region, and showing an unbalanced distribution of woody debris decay classes indicating a lack of recent LWD recruitment. Forests show stand closure between 15 years and 25 years in the region (Hayes et al. 1997, Deal and Tappeiner 2002), initiating a stem exclusion phase that may last up to 100 years (Tappeiner and Alaback 1989, Deal and Tappeiner 2002). Silvicultural thinning within riparian forests that are experiencing stem exclusion will help release the suppressed conifer species, especially Sitka spruce (Deal and Farr 1993, Hayes et al. 1997, Poulin 2000, Deal and Tappeiner 2002), while providing a pulse of woody debris in the system. Prior studies have demonstrated a strong positive radial growth relationship to thinning Sitka spruce-dominated stands (Deal and Farr 1993, Mitchell 2000, Deal and Tappeiner 2002), helping ensure future LWD recruitment.

Both riparian forests sampled lacked a diversity of decay states of downed wood. A relatively large quantity of downed wood, particularly large woody debris, is considered an important structural component for old-growth forest in the Pacific Northwest (Feller 2003). Having a variety of decomposition classes of dead wood enhances forest biodiversity because it offers a larger range of habitat structures for multiple species (Hayes et al. 1997). A steady input of newly dead trees is necessary to perpetuate LWD of varying classes available for recruitment into both terrestrial and aquatic environments. When periods of low tree mortality occur there are breaks in the temporal continuity of downed dead wood (Vanderwel et al. 2006).

Both riparian forests were also lacking the pole/sapling and regeneration layers of the canopy. The Sitka black-tailed deer (Odocoileus hemionus sitkensis [Cowan]) was introduced near the end of the $19^{\text {th }}$ century and now deer density esti- 

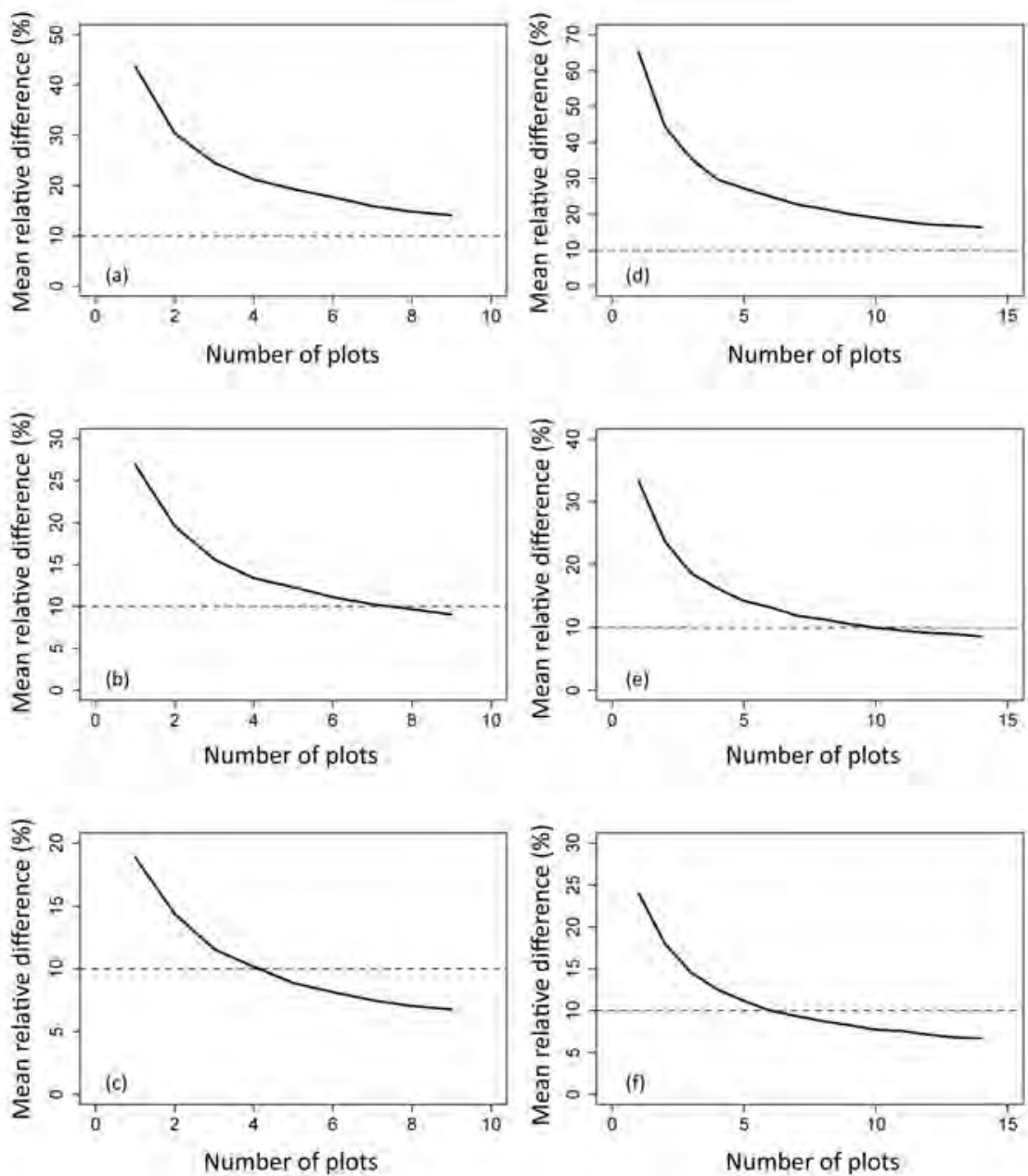

Fig. 4. Relationship between number of plots sampled and the mean relative difference between the variable measurement and the estimated true mean of that variable in the Sandy Creek watershed (a, b, c) and Powrivco Creek watershed (d, e, f). The variables are LWD volume (a, d), tree density (b, e), and basal area (c, f).

mates are between 13 and 30 deer per $\mathrm{km}^{2}$ throughout the islands (Vila et al. 2003b, Allombert et al. 2005). The Sitka black-tailed deer has been found to significantly modify plant diversity and vegetation structure on Haida Gwaii (Vila et al. 2002, 2003ab). Therefore, the lack of understory vegetation within the riparian forests on Lyell Island can be attributed largely to deer browse. Deer management may be necessary to ensure restoration success, especially within Gwaii Haanas where hunting pressure is low because of its national park status. High rates of ungulate browse on Haida Gwaii likely compound the lack of recruitment found during the prolonged stem exclusion period.

The 100-year model simulation of stand structure for the riparian forests surrounding Sandy Creek predicts an increase in average $\mathrm{DBH}$ and a decrease in stand density. This future projection of stand characteristics approximates a mature self-sustaining riparian forest approximately 165 years old, with a natural continuous recruitment of LWD. However, these model results should be viewed with caution, as FVS was not specifically designed for riparian areas. The model also does not take into account how stochastic disturbances that are common to riparian areas could affect stand development (Pollock et al. 2005). However, until riparian-specific models are developed, vegetation growth models are the best available models for predicting long-term consequences of riparian forest manipulations.

The simulation of accuracy of the monitoring plan illustrates that sampling efficiency depends strongly on the variable being measured. Calculations suggestion that seven to ten plots are sufficient to obtain values within $10 \%$ of the true mean of tree density and basal area for the riparian forests on Lyell Island. However, this number of permanent sample plots is not sufficient to accurately assess LWD volume by this criterion. There was also a higher measurement error associated with LWD volume, likely due to the difficulty in precise replication since line transects are not marked permanently as are overstory vegetation plots. If the placement of the line transect deviated by as little as one metre from the original placement, volume estimates for LWD could differ dramatically. The line transect method is a form of PPS (probability in proportion to size) sampling, and so is more efficient at determining LWD volume than are fixed area plots (Van Wagner 1968, Hazard and Pickford 1984, Caza 1993). However, several alternative PPS sampling methods for LWD have been developed and utilized that have higher sampling efficiency than line-intercept sampling (Bebber and Thomas 2003, Jordan et al. 2004, Woldendorp et al. 2004). Sampling methods that utilize a reference point rather than a line (Bebber and Thomas 2003, Williams and Gove 2003) would almost certainly have lower measurement error and higher repeatability, and would thus be especially well suited for monitoring programs. We therefore suggest that incorporation of point-based measurements should be examined in LWD monitoring programs, though the increased efficiency must be weighed against comparability with pre-existing programs and databases. 

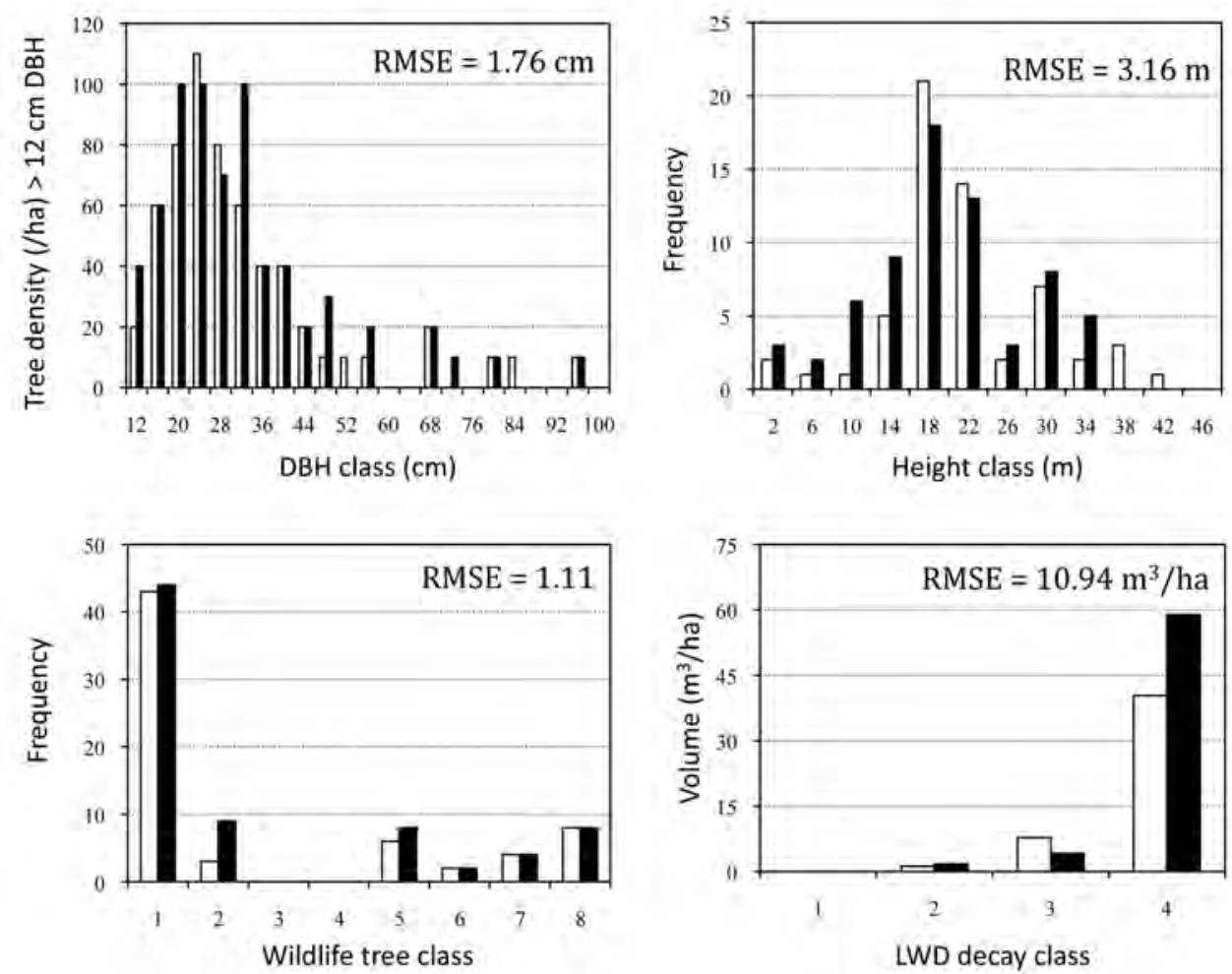

Fig. 5. Measurement error assessment of DBH (a), height (b), wildlife tree class (c), and LWD volume (d) from Powrivco Creek watershed. Repeated measurements of the same sample plots were collected on August $27^{\text {th }}$ (white bars) and August $28^{\text {th }}$ (black bars).

In conclusion, historically logged riparian forests on Lyell Island are currently in a stem-exclusion phase and lack a diversity of both downed wood types and understory vegetation. Forest simulation models predict that thinning of these stands will accelerate succession to approximate a mature selfsustaining riparian forest, one that naturally provides a continuous supply of LWD. The error analysis assessment of sampling efficiency indicates the current sampling design is efficient and effective at monitoring riparian forest stand dynamics, with the exception of LWD volumes. As this current research was limited temporally, more research is suggested to gain a comprehensive understanding of the sampling efficiency of the forest stand dynamic monitoring plan with respect to riparian restoration. In addition, the current monitoring design does not monitor vegetation in the active floodplain, as restoration is not being undertaken in this area. However, LWD deposited in the active floodplain creates conditions necessary for plant colonization, eventually adding to the recruitment of LWD for in-stream habitat structures (Fetherson et al. 1995). The probability of a tree within the riparian forest to enter the stream when it dies decreases with distance from the active channel (Fetherson et al. 1995); therefore, LWD recruitment is highest within the active floodplain. Additional vegetation monitoring within the active floodplain thus seems imperative.

\section{Acknowledgements}

We thank the Ministry of Forests, Lands and Natural Resource Operations, Haida Gwaii Natural Resource District, and in particular Leonard Munt, District Manager, and Sean Muise, Stewardship Forester, for making this work possible.

\section{References}

Allombert, S., S. Stockton and J.-L. Martin. 2005. A natural experiment on the impacts of overabundant deer on forest invertebrates. Cons. Biol. 19 (6): 1917-1929.

Banner, A., P. LePage, J. Moran and A. de Groot. 2005. The $\mathrm{HyP}_{3}$ Project: pattern, process, and productivity in hypermaritime forests of coastal British Columbia - a synthesis of 7-year results. Special Report 10. B.C. Ministry of Forests, Victoria, BC.

Bebber, D.P. and S.C. Thomas. 2003. Prism sweeps for coarse woody debris. Can. J. For. Res. 33: 1737-1743.

Beechie, T.J., G. Pess, P. Kennard, R.E. Bilby and S. Bolton. 2000. Modeling recovery rates and pathways for woody debris recruitment in Northwestern Washington streams. N. Am. J. Fish. Manage. 20: 436-452.

Caza, C.L. 1993. Woody debris in the forests of British Columbia: a review of the literature and current research. Land Management Report 78. B.C. Ministry of Forests, Victoria, BC.

Crookston, N.L. and G.E. Dixon. 2005. The forest vegetation simulator: a review of its structure, content and applications. Comput. Electron. Agric. 49: 60-80. 
Davis, T.J., B. Klinkenberg and C.P. Keller. 2004. Evaluating restoration success on Lyell Island, British Columbia using oblique videogrammetry. Res. Ecol. 12: 447-455.

Deal, R.L. and W.A. Farr. 1993. Composition and development of conifer regeneration in thinned and unthinned natural stands of western hemlock and Sitka spruce in southeast Alaska. Can. J. For. Res. 24: 976-984.

Deal, R.L. and J.C. Tappeiner. 2002. The effects of partial cutting on stand structure and growth of western hemlock-Sitka spruce stands in southeast Alaska. Forest Ecol. Manage. 159: 173-186.

Densmore, N., R. Thompson, D. McGeough and K. Kilpatrick. 2009. Protocol for stand-level biodiversity monitoring: steps for field data collection and administration. Forest and Range Evaluation Program, B.C. Ministry of Forest and Range and B.C. Ministry of the Environment, Victoria, BC.

Feller, M.C. 2003. Coarse woody debris in old-growth forests of British Columbia. Environ. Rev. 11: 135-157.

Fetherston, K.L., R.J. Naiman and R.E. Bilby. 1995. Large woody debris, physical process, and riparian forest development in montane river networks of the Pacific Northwest. Geomorph. 13: 133-144.

Gertner, G.Z. 1990. The sensitivity of measurement error in stand volume estimates. Can. J. For. Res. 20: 800-804.

Hayes, J.P., S.S. Chan, W.H. Emmingham, J.C. Tappeiner, L.D. Kellogg and J. Bailey. 1997. Wildlife response to thinning young forests in the Pacific Northwest. J. For. 95: 28-33.

Hazard, J.W. and S.G. Pickford. 1984. Cost functions for the line intersect method of sampling forest residue in the Pacific Northwest. Can. J. For. Res. 14: 57-62.

Herrick, J.E., G.E. Schuman and A. Rango. 2006. Monitoring ecological processes for restoration projects. J. Nat. Cons. 14: 161-171. Johnston, N.T., K. Calla, N.E. Down, J.S. Macdonald, E.A. MacIsaac, A.N. Witt and E. Woo. 2007. A review of empirical source distance data for the recruitment of large woody debris to forested streams. Fisheries Project Report RD119, B.C. Ministry of Environment, Victoria, BC.

Jordan, G.J., M.J. Ducey and J.H. Gove. 2004. Comparing lineintersect, fixed-area, and point relascope sampling for dead and downed coarse woody material in a managed northern hardwood forest. Can. J. For. Res. 34: 1766-1775.

Keyser, C.E. 2011. Southeast Alaska and coastal British Columbia (AK) variant overview. USDA Forest Service, Fort Collins, CO.

Kondolf, G.M. and E.R. Micheli. 1995. Evaluating stream restoration projects. Environ. Manag. 19: 1-15.

Manly, B.F.J. 2007. Randomization, bootstrap and Monte Carlo methods in biology. Chapman and Hall, Boca Raton, FL.

Mitchell, S.J. 2000. Stem growth response in Douglas-fir and Sitka spruce following thinning: implications for assessing wind-firmness. Forest Ecol. Manage. 135: 105-114.

Opperman, J.J. and A.M. Merenlender. 2004. The effectiveness of riparian restoration for improving instream fish habitat in four hardwood dominated California streams. N. Am. J. Fish. Manage. 24: 822-834.

Parks Canada. 2011. Yahgudang dlljuu: A Respectful Act. Gwaii Haanas National Park Reserve, National Marine Conservation Area Reserve, and Haida Heritage Site, Queen Charlotte, BC.

Phillips, D.L., S.L. Brown, P.E. Schroeder and R.A. Birdsey. 2000.
Towards error analysis of large-scale forest carbon budgets. Global Ecol. Biogeog. 9: 305-313.

Pollock, M.M., T.J. Beechie, S.S. Chan, and R. Bigley. 2005. Monitoring restoration of riparian forests. In P. Roni (ed.). Monitoring stream and watershed restoration. pp. 67-96. American Fisheries Society, Bethesda, MD.

Poulin, V.A., C. Harris and B. Simmons. 2000. Riparian restoration in British Columbia: what's happening now, what's needed for the future. B.C. Ministry of Forests, Victoria, BC.

R Development Core Team. 2011. R: a language and environment for statistical computing. R Foundation for Statistical Computing, Vienna, Austria.

Roni, P. 2005. Overview and background. In P. Roni (ed.). Monitoring stream and watershed restoration. pp. 1-11. American Fisheries Society, Bethesda, MD.

Ruiz-Jaen, M.C. and T.M. Aide. 2005. Restoration success: how is it being measured? Res. Ecol. 13: 569-577.

Takeda, L. and I. Røpke. 2010. Power and Contestation in collaborative ecosystem-based management: the case of Haida Gwaii. Ecol. Econ. 70: 178-188.

Tappeiner, J.C. and P.B. Alaback. 1989. Early establishment and vegetation growth of understory species in the western hemlockSitka spruce forests of southeast Alaska. Can. J. Bot. 67: 318-326.

U.S. Forest Service. 1996. Forest vegetation simulator. U.S. Forest Service, Fort Collins, CO.

Van Wagner, C.E. 1968. The line intersect method in forest fuel sampling. Forest Sci. 14: 20-26.

Vanderwel, M.C., J.R. Malcom and S.M. Smith. 2006. An integrated model for snag and downed woody debris decay class transitions. Forest Ecol. Manage. 234: 48-59.

Vila, B., G. Vourch, D. Gillon, J.L. Martin and F. Guibal. 2002. Is escaping deer browse just a matter of time in Picea sitchensis? A chemical and dendroecological approach. Trees 16: 488-496.

Vila, B., F. Torre, F. Guibal and J.L. Martin. 2003a. Growth change of young Picea sitchensis in response to deer browsing. Forest Ecol. Manag. 180: 413-424.

Villa, B., F. Torre, J.L. Martin and F. Guibal. 2003b. Response of young Tsuga heterophylla to deer browsing: developing tools to assess deer impact on forest dynamics. Trees 17: 547-553.

Welty, J.J., T. Beechie, K. Sullivan, D.M. Hyink, R.E. Bilby, C. Andrus and G. Pess. 2002. Riparian aquatic interaction simulator (RAIS): a model of riparian forest dynamics for the generation of large woody debris and shade. Forest Ecol. Manage. 162: 299-318.

Williams, M.S. and J.H. Gove. 2003. Perpendicular distance sampling: an alternative method for sampling downed coarse woody debris. Can. J. For. Res. 33: 1564-579.

Wissmar, R.C. and R.L. Beschta. 1998. Restoration and management of riparian ecosystems: a catchment perspective. Freshwater Biol. 40: 571-585.

Woldendorp, G., R.J. Keenan, S. Barry and D.R. Spencer. 2004. Analysis of sampling methods for coarse woody debris. Forest Ecol. Manage. 198: 133-148. 